\section{Harnessing of corneas captured and processed for transplantation in an ocular tissue bank of North-eastern Brazil}

\author{
Aproveitamento das córneas captadas e processadas para \\ transplante em um banco de tecidos oculares do Nordeste
}

Aprovechamiento de las córneas capturada y procesada

para trasplante en un banco de tejidos oculares del Noreste

\author{
Izaura Luzia Silvério Freire ${ }^{a}$ \\ Micheline da Fonseca Silva ${ }^{b}$ \\ Andrea Tayse de Lima Gomes ${ }^{c}$ \\ Quinidia Lúcia Duarte de Almeida Quithé de Vasconcelos ${ }^{\mathrm{d}}$ \\ Rhayssa de Oliveira e Araújo \\ Gilson de Vasconcelos Torres ${ }^{f}$
}

\begin{abstract}
The aim of this study was to describe the harnessing of corneas captured and processed for transplantation in an ocular tissue bank in north-eastern Brazil. This was a transverse and retrospective study, with a sample group of 612 individuals whose corneas were donated and captured between January/2007 and July/2012. This study was approved by the Research Ethics Committee under number 007.0.294.000-10, and research was based on an instrument consisting of social, demographic and clinical data of the donors. Of the 1209 corneas captured, 868 were used and 341 were discarded. Of the 612 donors, the corneas of 597 (97.5\%) were captured from both eyes, being that 423 (70.9\%) of these corneas were used. Further studies are required on the reasons for discarding corneas and clarifications as to the conduct of professionals when processing corneas, considering the increase in the quantity of donors and the elevated number of discarded ocular tissue.
\end{abstract}

Descriptors: Corneal transplantation. Tissue and organ harvesting. Tissue banks.

\section{RESUMO}

Objetivou-se descrever 0 aproveitamento das córneas captadas e processadas para transplante em um banco de tecidos oculares do Nordeste. Estudo transversal e retrospectivo, com amostra de 612 pessoas que tiveram suas córneas doadas e captadas, entre janeiro de 2007 a julho de 2012. Após a aprovação pelo Comitê de Ética em Pesquisa, de número 007.0.294.000-10, utilizou-se um instrumento composto por dados sociodemográficos e clínicos dos doadores. Das 1.209 córneas captadas, 868 foram utilizadas e 341 descartadas. Dos 612 doadores, 597 (97,5\%) tiveram captação das córneas dos dois olhos e, dentre estas, 423 (70,9\%) foram utilizadas. Necessita-se de mais estudos sobre causas de descartes de córneas e esclarecimentos quanto à conduta dos profissionais no processamento destas, visto o aumento da quantidade de doadores e o número elevado de descartes de tecidos oculares.

Descritores: Transplante de córnea. Coleta de tecidos e órgãos. Bancos de tecidos.

\section{RESUMEN}

El objetivo fue describir el aprovechamiento de las córneas capturada y procesada para trasplante en un banco de tejidos oculares del noreste. Estudio transversal y retrospectivo, con una muestra de 612 personas que tenían sus córneas donadas y capturados entre enero/2007 a julio/2012. Después de la aprobación del Comité de Ética de Investigación de número 007.0.294.000-10, se utilizó un instrumento que consiste en datos sociodemográficos y clínicos de los donantes. De las 1.209 córneas capturadas, 868 se utilizaron y 341 se desecharon. De los 612 donantes, 597 (97,5\%) tenían capitación de las córneas de los dos ojos, entre estos, se utilizaron 423 (70,9\%). Necesidad de ser de más estudios sobre las causas de los vertidos de la córnea y aclaraciones a la conducta de los profesionales en el procesamiento de estos, al ver el aumento en la cantidad de donantes y el elevado número de desechados de los tejidos oculares.

Descriptores: Trasplante de córnea. Recolección de tejidos y órganos. Bancos de tejidos.
D0l: $\quad$ http://dx.doi.org/10.1590/19831447.2014.03.44830 


\section{口INTRODUCTION}

Corneal diseases are the second cause of reversible blindness in the world, and are responsible for incapacitating a significant portion of the active young population, generating social and economic losses to the community ${ }^{(1)}$. Corneal pathologies are reversible due to the possibility of correction by means of corneal transplants or keratoplasty.

The cornea is considered a immunologically privileged tissue because it presents less risk of rejection in comparison to other parts of the human body. Moreover, advancements in immunology, pharmacology, ocular microsurgery and a better organization of Ocular Tissue Banks (OTB) enable the realization of transplants in cases that were previously considered inoperable ${ }^{(2-3)}$.

It is worth noting that corneas should be captured in no longer than six hours when in non-refrigerated bodies, and in no longer than 24 hours in refrigerated bodies. Subsequently, tissue is processed, which consists of biomicroscopical assessment, preservation in a specific medium and counting of endothelial cells, in less than 60 minutes. Only after three days from capturing, which is the time needed for the serum screening required by national laws, can corneas be made available for transplant scheduling ${ }^{(4)}$.

The eye doctor can observe quality of corneas by means of specular microscopy and use of slit lamp resources. The use of these techniques, that are specifically conducted at the $\mathrm{OTB}$, are very important in the evaluation and selection process of corneas suitable for transplantation. Moreover, these institutions are responsible, after evaluation, for accepting or rejecting donated tissue and for deciding which corneal tissue is available for transplant, in addition to making institution files available for at least 20 years. ${ }^{(5-7)}$.

The OTB plays an important role in seeking, capturing, preserving and distributing corneas for transplantation. An increase in the number and effectiveness of transplants is the result of extended rigor in tissue quality control at the eye banks, which starts with donor selection, use of an adequate enucleation technique, preservation of the cornea and assessment of parameters, such as donor serology and endothelial cell count ${ }^{(6)}$.

Good quality and correct maintenance of corneas knowingly contribute to positive results. Furthermore, there are some factors that influence the quality of captured corneas, including age of the donor, being that the older the donor, the greater the probability of anatomic alterations to corneal tissue; cause of death of the donor, considering that individuals with degenerative diseases have poorer corneal quality; time of permanence of the cornea in the conservation media, being that extended time of tissue in conservation media may lead to poorer quality of donated corneas and primary failure ${ }^{(5)}$.

The OTB is responsible for searching for donors and interviewing the families, capturing donated ocular tissue, receiving ocular tissue captured by other institutions, and for guaranteeing the verification of clinical screening and laboratory tests to analyse possible contradictions. The OTB is also responsible for evaluating, preserving and storing ocular tissue. In Brazil, the OTB inspection route is based on the Collegiate Directorate Resolution (RDC) no 67, of September 30, 2008, which establishes Technical Regulations for the operation of human OTBs ${ }^{(7)}$.

In view of the number of donated and discarded corneal tissue, the following question was created: How does capturing and processing occur and what is the extent of harnessing donated corneas for transplantation in an ocular tissue bank in Rio Grande do Norte?

In this context, this study is expected to increase an understanding of this process, from donation of tissue by family members to implantation in the recipient, and create awareness in the involved actors of its importance for bettering the quality of life of individuals. Consequently, the aim of this study is to describe harnessing of corneas captured and processed for transplantation in an OTB in north-eastern Brazil.

\section{METHODS}

This is a transversal and retrospective study conducted in the OTB of Rio Grande do Norte (RN). Data were collected from August to September, 2012. The study population consisted of all individuals whose corneas were donated and captured between January 2007 and July 2012, totalling 612 donors.

Data were collected using a structured non-participative observation script created especially for this study, consisting of two parts: the first containing social, demographic and clinical data of the donor, such as sex, age, origin and medical diagnosis (according to International Classification of Diseases - ICD 10). The second part included variables related to corneas: quantity of captured, processed, discarded and transplanted tissue.

The study instrument was pre-tested by the research group Incubator of Nursing Procedures of the Federal University of Rio Grande do Norte (UFRN), after the eight-hour extension course on the donation of organs and tissue for transplantation. The instrument suffered minor alterations in its wording, layout, content, sequence, categorization 
and coding of information to improve its applicability and suitability for the purposes of this study.

After approval of the research project by the Research Ethics Committee of the Onofre Lopes University Hospital (CEP/HUOL) with protocol number 414/10, and the Presentation Certificate for Ethical Appreciation (CAAE) 007.0.294.000-10, according to Ethical and Legal Aspects of Scientific Research, established by Resolution $466 / 12$ of the National Health Counsel ${ }^{(8)}$, information was collected by two researchers and five under-graduate nursing students of the UFRN, linked to the research base Incubator of Nursing Procedures, in the OTB-RN database.

Data were subsequently transferred and arranged using Microsoft-Excel 2007M. Data were then transferred to statistical SPSS software version 20.0, were they were analysed using descriptive statistics by means of absolute and relative frequencies

\section{RESULTS}

Data collected at the OTB of Rio Grande do Norte referent to donation, capturing and transplantation of corneas between January 2007 and July 2012 showed that the number of donors during the collection period was 612 and the amount of corneal tissue captured was 1209, of which 868 (71.8\%) was used for transplants and 341 (28.2\%) were discarded.

Among the donors, there was a predominance of men (71.4\%), between the ages of 41 and 60 (41.3\%), with an average age of 42.5 ( \pm 16.8 years), a minimum age of 3 years and a maximum of 73 years. Most donors came from the metropolitan region of Natal/RN (71.1\%) and main diagnosed causes of death were: external causes (36.9\%), diseases of the nervous system (29.2\%) and circulatory diseases (17.3\%), as shown in Table 1.

Of the 612 cornea donors, 597 (97.5\%) had corneas captured from both eyes, of which $70.9 \%$ were used. A total of 15 (2.5\%) were donors of corneal tissue from one eye only, of which $0.9 \%$ were used.

Figure 1 shows that, of the corneas captured from both eyes, $70.9 \%$ were used, while in those that were donated from one eye only, the harnessing rate was $0.9 \%$. Of the captured tissue, $28.2 \%$ of corneas were discarded.

Figure 2 shows the low harnessing rate of corneas captured from one eye, between 2007 and 2009. However, during that same period, corneal tissue captured from two eyes had a higher suitability rate for transplantation. The figure also shows that between 2010 and 2011, the number of corneas for transplantation
Table 1 - Characterization of cornea donors of the state of RN from 2007 to 2012. Natal/RN/Brazil, 2013.

\begin{tabular}{|c|c|c|}
\hline \multirow{2}{*}{ Cornea donors } & \multicolumn{2}{|c|}{$\begin{array}{c}\text { Donors } \\
n=612 \\
\end{array}$} \\
\hline & $\mathbf{N}$ & $\%$ \\
\hline \multicolumn{3}{|l|}{ Sex } \\
\hline Male & 437 & 71.4 \\
\hline Female & 175 & 28.6 \\
\hline \multicolumn{3}{|l|}{ Age group } \\
\hline 1 to 20 (minimum age of 3 years) & 75 & 12.3 \\
\hline 21 to 40 & 190 & 31 \\
\hline 41 to 60 & 253 & 41.3 \\
\hline Over 60 & 94 & 15.4 \\
\hline
\end{tabular}

\section{Origin}

$\begin{array}{lcc}\text { Metropolitan } & 435 & 71.1 \\ \text { Interior } & 171 & 27.9 \\ \text { Other state } & 6 & 1\end{array}$

\section{Diagnosis}

\begin{tabular}{lcc} 
External causes & 226 & 36.9 \\
Nervous system & 179 & 29.2 \\
Circulatory & 106 & 17.3 \\
Respiratory & 39 & 6.4 \\
Digestive & 23 & 3.8 \\
Infectious disease & 14 & 2.3 \\
To define & 12 & 2 \\
Blood disease & 6 & 1 \\
Neoplasia & 4 & 0.7 \\
Endocrinous & 3 & 0.5 \\
\hline
\end{tabular}

Source: Data from the Ocular Tissue Bank database of RN, from January 2007 to July 2012. Natal/RN/Brazil.

dropped due to the higher number of discarded corneas in this period.

The number of corneas used for transplantation rose sharply from 2008 to 2011, and donation of corneal tissue also grew steadily in the same period. In 2012, there was a reduction in the donation rate and use of corneas (Figure 3).

In terms of the causes for discarding corneas in Rio Grande do Norte, the main reasons were poor tissue quality (31.1\%), and stromal infiltration (23.2\%), followed by anti HBC positive serum (20.5\%) (Figure 4). Inconclusive serum screening and the impossibility of obtaining blood from the donor. 


\section{DISCUSSION}

The characterization of cornea donors in the state of RN between 2007 and 2012, showed the predominance of men. This fact is justified by the prevalence of men in serious violent trauma, such as gunshot wounds or knife wounds, and that men are more commonly involved in car accidents ${ }^{(9-11)}$

In relation to age, data showed that age ranged from 3 to 73 years, with average age of 42.5 years. Consequently, the sample comprised a heterogeneous group in terms of age, ranging from children to elderly individuals.

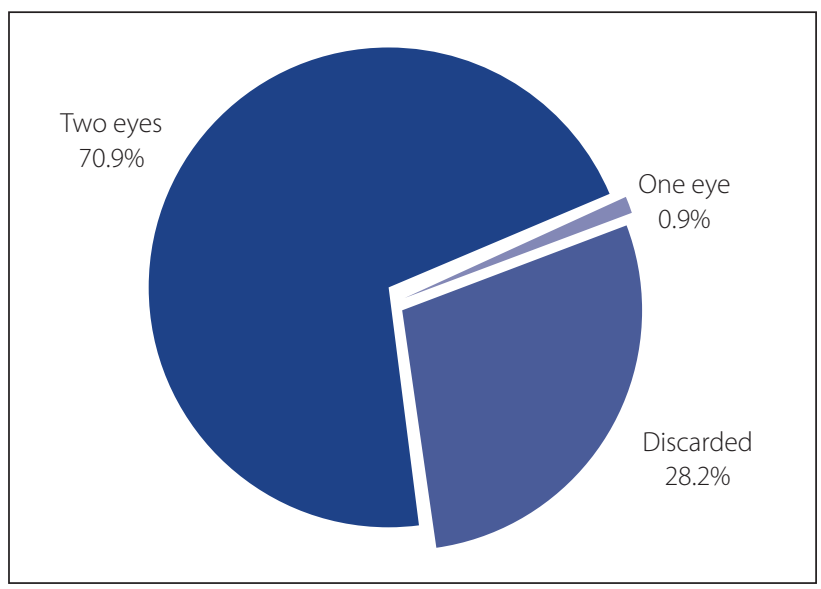

Figure 1 - Percentage of corneas harnessed and discarded by the OTB for transplantation, from 2007 to 2012. Natal/ RN/Brazil, 2013.
Also in relation to age, literature shows that the corneal tissue of elderly donors can suffer a greater loss of endothelial cells, which can compromise the final result of transplants ${ }^{(6,12)}$. Corroborating another study ${ }^{(12)}$, findings of this research show that of the 118 elderly donors, 240 corneas were captured, but only 131 corneas were effectively harnessed for transplantation.

A study conducted at an eye bank showed that age of the donor was more relevant than cause of death and conservation time of the cornea after death in relation to number of endothelial calls ${ }^{(13)}$. Data of this study corroborate with findings in literature in the sense that the age factor was more relevant in relation to cause of death.

A study conducted in São Paulo from October 2002 to September 2004, showed that discard rates of captured corneas totalled 216, which is much lower than the numbers found in this study. The causes for discarding corneas are stromal infiltration, positive serology, time frame of transplant, poor quality and sepsis ${ }^{(14-15)}$. Data found in the study above corroborate with the findings of this study, in which the main causes that led to discarded corneas were poor tissue quality and stromal infiltration, followed by anti HBc-positive serum.

Stromal infiltration consists of an infiltration in the tissue that sustains the functional components of the eye, called stroma. This type of infiltration makes tissue transplantation impossible, as the aetiology of the lesion is unknown ${ }^{(14)}$.

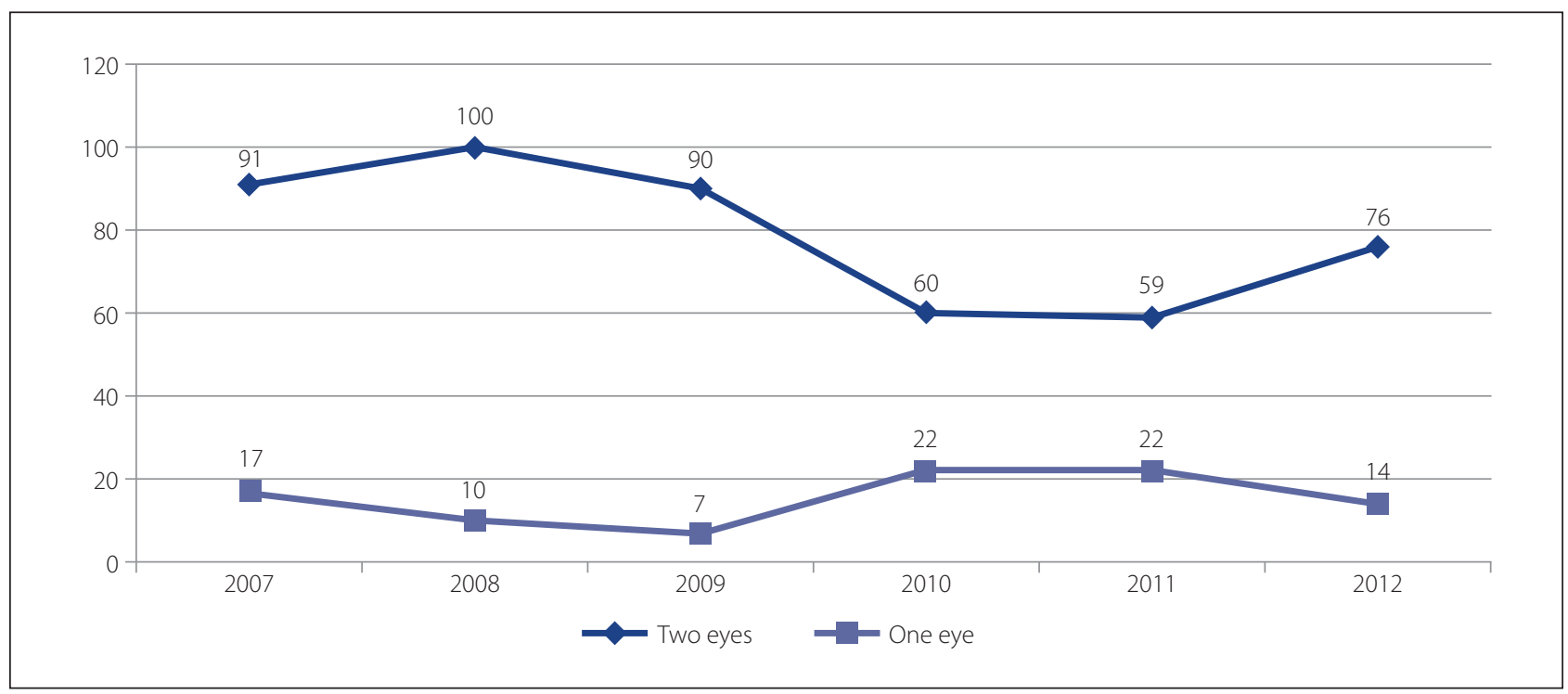

Figure 2 - Distribution of tissue for transplantation according to the number of corneas harnessed from one and two eyes from 2007 to 2012. Natal/RN/Brazil, 2013 


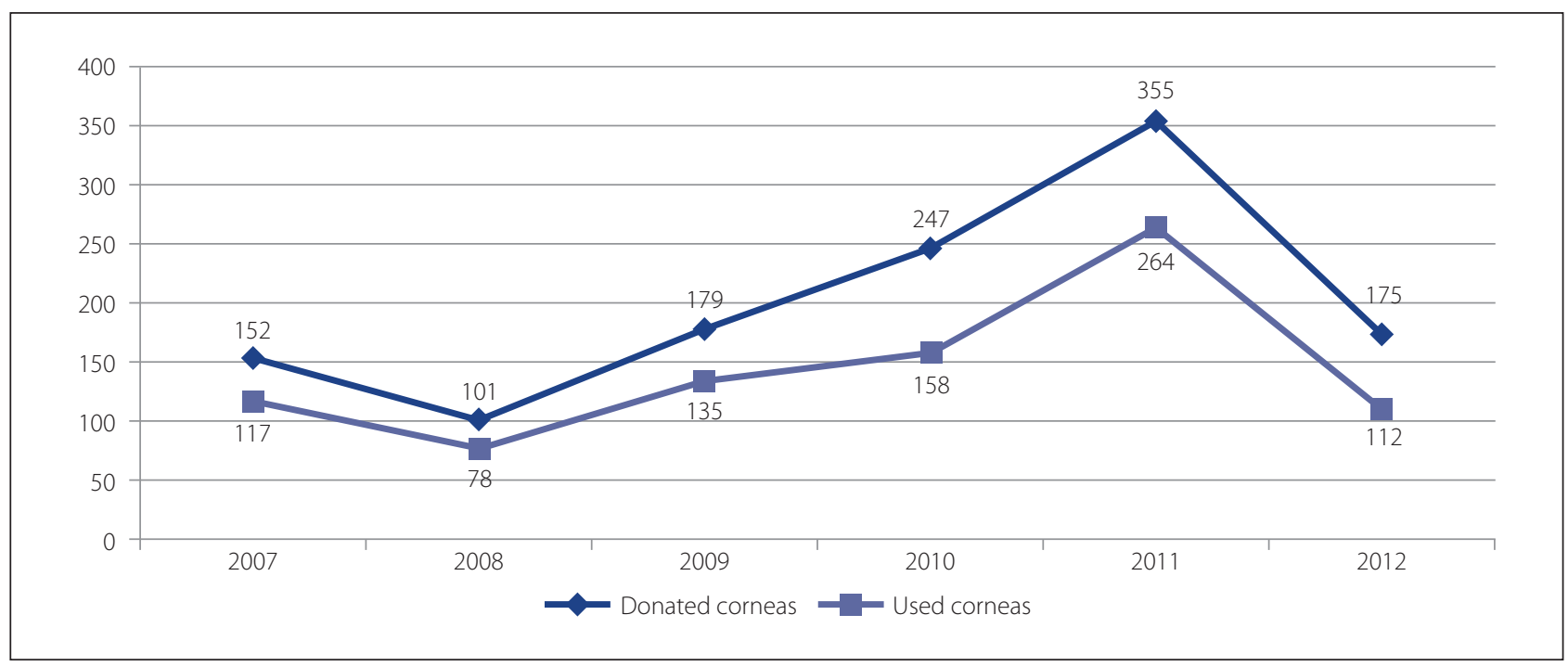

Figure 3 - Distribution of donated and used corneas for transplantation from 2007 to 2012. Natal/RN/Brazil, 2013.

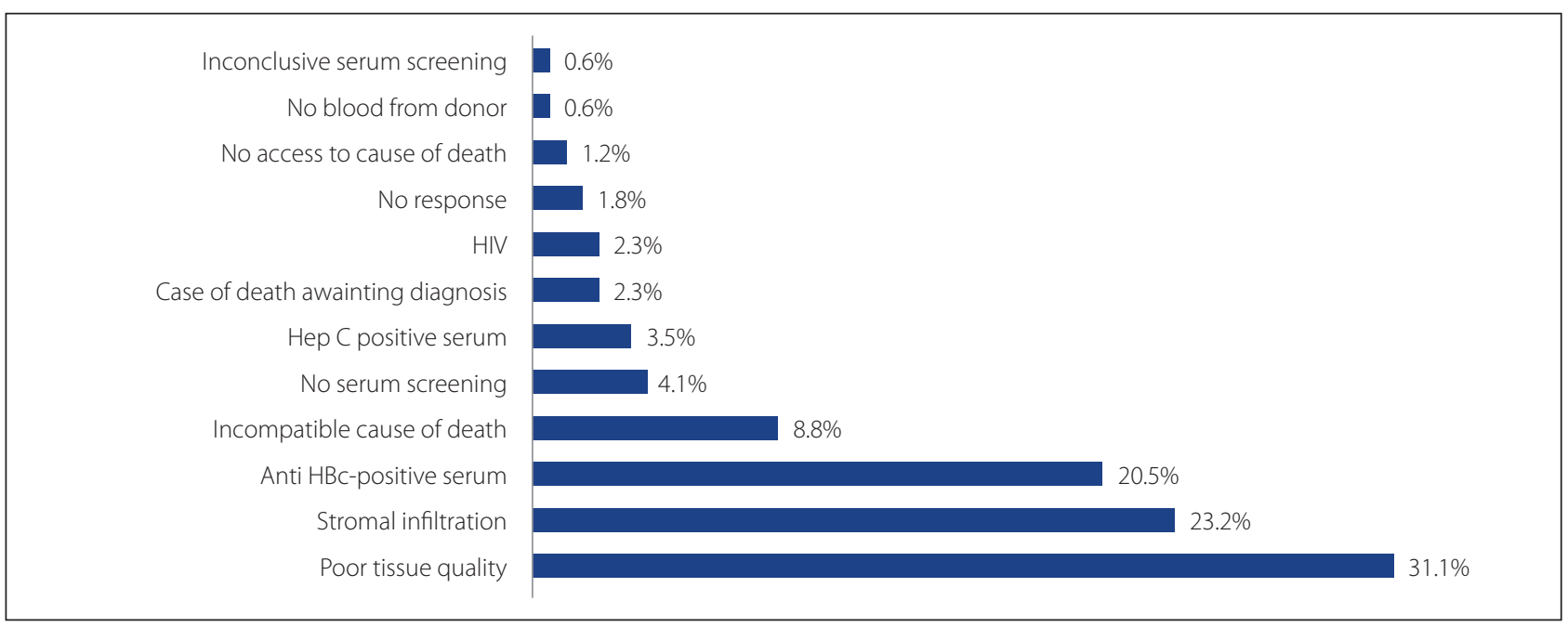

Figure 4 - Distribution of causes for discarding corneas from 2007 to 2012. Natal/RN/Brazil, 2013.

Incorrect use of the capturing and preservation technique is one of the causes of corneal tissue loss ${ }^{(6,9)}$. It is believed that corneal tissue may also be compromised during the hospital stay period, especially in the case of inadequate care in relation to preservation of corneas or during the stage between death of the individual and capturing of the tissue. Consequently, ocular care, such as lubricating the eyes during the hospital stay period and closing the eye lids after death are essential to guarantee good quality corneas.

Even in cases when tissue is maintained in adequate preservation media for no more than 14 days, a study shows that there can be endothelial loss and primary failure when the seven-day period after capturing has passed ${ }^{(6)}$.

This same study showed a sharp increase in donated and used corneas from 2008 and 2011, with the advent of the Organ Procurement Organization (OPO) in RN.

It should be noted that the OPOs or Cornea Organization and Procurement (OPC) and the Unified List System for Cornea Transplants were created in 2000 by the Ministry of Health, after which eye banks became standardized. Before the creation of the OPOs and OPCs, corneas were preserved and used only in the institution in which they were captured ${ }^{(7)}$. 
By considering cornea transplantation and its specializations, the Pan-American Eye Bank Association that seeks to reduce the number of visual impairment caused by corneal problems, is conducting yearly training in Brazil and Colombia that addresses the technical, scientific, administrative, legal and ethical aspects of eye banks and cornea transplants ${ }^{(16)}$.

The OPOs have a multi-professional structure and basically consist of physician, nurses and social worker. The healthcare team, especially the nurses, must know that providing qualified care during hospitalization, clarifying queries related to encephalic death and clearance of the body are extremely important for the organ donation process, and are factors that may contribute to the reduction of pain and suffering of the donor's family and support the decision-making process in relation to donation (17).

The role of OPOs is to identify potential donors until the conversion into effective donors, contact the hospital unit where the patient is admitted to obtain information, such as age, haemodynamic conditions, cause of death and death diagnosis time, identify absolute counter-indications that may exclude the donor, inform the teams about which organs will be removed, and the time of the procedure ${ }^{(18-19)}$.

\section{- CONCLUSIONS}

In this study, most of the donors were men, between the ages of 41 and 60, from the metropolitan region of $\mathrm{Na}$ tal, with cause of death diagnosed as external causes.

In relation to corneas for transplantation, in most donors, harnessed corneas were captured from both eyes, although the number of discarded corneas was higher than the number of discarded corneas in other OTBs in the country. Furthermore, there was a greater number of transplants between 2008 and 2011. In 2012, however, the lowest cornea donation rates were registered in the OTB-RN.

In relation to discarded corneal tissue, the leading causes were poor tissue quality and stromal infiltration and, to a lesser degree, inconclusive serum results and non-obtainment of the donor's blood.

These results reveal the need for further studies on the causes for discarding corneas, and further clarification on the conduct of professionals that specialize in tissue harvesting, as there was a significant increase in the number of donors, but the amount of discarded ocular tissue was considered high. Studies of this nature will guide professionals to assure the best quality corneas for transplantation.

\section{REFERENCES}

1. Adán CBD, Diniz AR, Periatto D, Hirai FE, Sato EH. Dez anos de doação de córneas no banco de olhos do Hospital São Paulo: perfil dos doadores de 1996 a 2005.
Arq Bras Oftalmol [Internet]. 2008 [cited in 2013 oct 09];71(2):176-81. Available in: http://www.scielo.br/pdf/abo/v71n2/a09v71n2.pdf

2. Sano FT, Dantas PEC, Silvino WR, Sanchez JZ, Sano RY, Adams F, et al. Tendência de mudança nas indicações de transplante penetrante de córnea. Arq Bras Oftalmol [Internet]. 2008 [cited in 2013 out 09];71(3):400-4. Available in: http:// www.scielo.br/pdf/abo/v71n3/a18v71n3.pdf

3. Yalniz-Akkaya Z, Burcu NA, Yildiz EH, Onat M, Budak K, Duman S. Repeat penetrating keratoplasty: indications and prognosis, 1995-2005. Eur J Ophthalmol [Internet]. 2009 [cited in 2013 out 09];19(3):362-8. Available in: http://medlib. yu.ac.kr/eur_j_oph/ejo_pdf/ejo_19_362.pdf

4. Silva RF, Vargas NU, Rocha GA, Freitas ML, Souza LB, Moreno NP. Avaliação de tecido corneano processado por um banco de olhos de referência. Arq Bras Oftalmol [Internet]. 2009 [cited in 2013 oct 09];72(5):673-6. Available in: http:// www.scielo.br/pdf/abo/v72n5/15.pdf

5. Sano RY, Sano FT, Dantas MCN, Lui ACF, Sano ME, Lui Neto A. Análise das córneas do banco de olhos da Santa Casa de São Paulo utilizadas em transplantes. Arq Bras Oftalmol [Internet]. 2010 [cited in 2013 oct 09];73(3):254-8. Available in: http://www.scielo.br/pdf/abo/v73n3/a09v73n3.pdf

6. Ministério da Saúde (BR). Portaria no 2.600 de 21 de outubro de 2009. Aprova 0 regulamento técnico do sistema nacional de transplantes. Diário Oficial da União [da] República Federativa do Brasil. 2009 out 30;146(208 Seção 1):77-118.

7. Ministério da Saúde (BR), Agência Nacional de Vigilância Sanitária. Resolução-RDC no 67 de 30 de setembro de 2008. Dispõe sobre o regulamento técnico para o funcionamento de bancos de tecidos oculares de origem humana. Diário Oficial da União [da] República Federativa do Brasil. 2008 out 01;145(190 Seção 1):62-64.

8. Ministério da Saúde (BR). Conselho Nacional de Saúde. Resolução nº 466, de 12 de dezembro de 2012. Diretrizes e normas regulamentadoras de pesquisas envolvendo seres humanos. Diário Oficial da União [da] República Federativa do Brasil. 2013 jun 13;150(112 Seção 1):59-62.

9. Hirai FE, Adán CBD, Sato EH. Fatores associados à qualidade da córnea doada pelo banco de olhos do Hospital São Paulo. Arq Bras Oftalmol [Internet]. 2009 [cited in 2013 oct 09];72(1):57-61. Available in: http://www.scielo.br/pdf/ abo/v72n1/v72n1a11.pdf

10. Viegas MTC, Pessanha LC, Sato EH, Hirai FE, Adán CBD. Descarte de córneas por sorologia positiva do doador no banco de olhos do Hospital São Paulo: dois anos de estudo. Arq Bras Oftalmol [Internet]. 2009 [cited in 2013 oct 09];72(1):1804. Available in: http://www.scielo.br/pdf/abo/v72n2/09.pdf

11. Mouro SDS, Guillens LC, Almeida TC, Duran ECM, Toledo VP. Causas da não efetivação de potenciais doadores em doadores reais: um estudo exploratório-descritivo. Rev Enferm UFPE on line [Internet]. 2012 [cited in 2013 oct 09];6(3):613-8. Available in: http://www.revista.ufpe.br/revistaenfermagem/ index.php/revista/article/view/2278/pdf_1026

12. Pantaleão GR, Zapparolli M, Guedes GB, Dimartini Junior WM, Vidal CC, Wasilewski D, et al. Avaliação da qualidade das córneas doadoras em relação à idade do doador e causa do óbito. Arq Bras Oftalmol [Internet]. 2009 [cited in 2013 oct 09];72(5):631-5. Available in: http://www.scielo.br/pdf/abo/v72n5/06.pdf

13. Costa DC, Kara-José N. Rejeição de transplante de córnea. Rev Bras Oftalmol [Internet]. 2008 [cited in 2013 oct 09];67(5):255-63. Available in: http://www. scielo.br/pdf/rbof/v67n5/v67n5a11.pdf

14. Santos CG, Pacini KM, Adán CBD, Sato EH. Motivos do descarte de córneas captadas pelo banco de olhos do Hospital São Paulo em dois anos. Rev Bras Oftalmol [Internet]. 2010 [cited in 2013 oct 09];69(1):18-22. Available in: http://www. scielo.br/pdf/rbof/v69n1/04.pdf 
15. Freire ILS. Fatores associados à efetividade da doação de órgãos e tecidos para transplantes [tese]. Natal (RN): Departamento de Enfermagem, Universidade Federal do Rio Grande do Norte; 2013.

16. Associação Pan-Americana de Banco de Olhos [Internet]. Pouso Alegre [cited in 2014 may 11]. Curso oficial; [aprox. 1 tela]. Available in: http://www.apabo. com.br/sobre-0-curso/

17. CinqueVM, Bianchi ERF. A tomada de decisão das famílias para a doação de órgãos. Cogitare Enferm [Internet]. 2010 [cited in 2014 july 07];15(1):69-73. Available in: http://ojs.c3sl.ufpr.br/ojs/index.php/cogitare/article/view/17174/11309
18. Mattia AL, Barbosa MH, Rocha AM, Rodrigues MB, Freitas Filho JPA, Oliveira MG. Análise das dificuldades no processo de doação de órgãos: uma revisão integrativa da literatura. Bioethikos [Internet]. 2010 [cited in 2013 oct 09];4(1):66-74. Available in: http://www.saocamilo-sp.br/pdf/ bioethikos/73/66a74.pdf

19. Pereira WA, Fernandes RC, Soler WV. Diretrizes básicas para captação e retirada de múltiplos órgãos e tecidos da Associação Brasileira de Transplante de Órgãos. São Paulo: AOTB; 2009 [citado 2014 may 11]. Available in: http://www.abto. org.br/abtov03/Upload/pdf/livro.pdf

\section{Author's address:}

Izaura Luzia Silvério Freire

Rua São João, 1233, ap. 601, bloco A, Lagoa Seca

59022-390, Natal, RN

E-mail: izaurafreire@hotmail.com
Received: 28.01.2014

Approved: 11.07.2014 